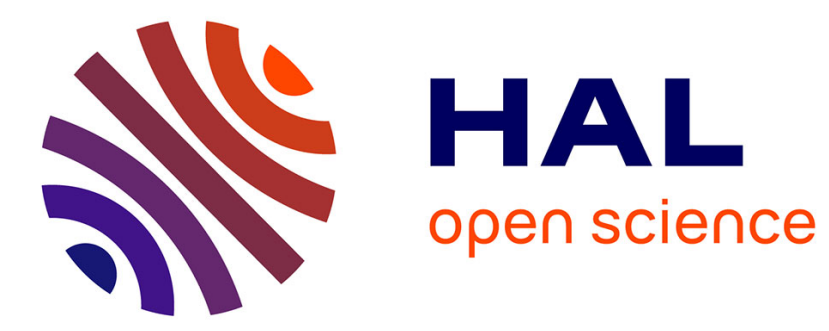

\title{
Si/Si1-x Gex/Si heterostructure growth by ultraclean low-temperature LPCVD for the fabrication of novel heterodevice
}

J. Murota, T. Maeda, K. Goto, K. Sakamoto, K. Aizawa, S. Ushioda, S. Ono

\section{- To cite this version:}

J. Murota, T. Maeda, K. Goto, K. Sakamoto, K. Aizawa, et al.. Si/Si1-x Gex/Si heterostructure growth by ultraclean low-temperature LPCVD for the fabrication of novel heterodevice. Journal de Physique IV Proceedings, 1993, 03 (C3), pp.C3-403-C3-410. 10.1051/jp4:1993356 . jpa-00251413

HAL Id: jpa-00251413

https://hal.science/jpa-00251413

Submitted on 1 Jan 1993

HAL is a multi-disciplinary open access archive for the deposit and dissemination of scientific research documents, whether they are published or not. The documents may come from teaching and research institutions in France or abroad, or from public or private research centers.
L'archive ouverte pluridisciplinaire HAL, est destinée au dépôt et à la diffusion de documents scientifiques de niveau recherche, publiés ou non, émanant des établissements d'enseignement et de recherche français ou étrangers, des laboratoires publics ou privés. 


\title{
$\mathrm{Si} / \mathrm{Si}_{1-x} \mathbf{G e}_{x} / \mathrm{Si}$ heterostructure growth by ultraclean low-temperature LPCVD for the fabrication of novel heterodevice
}

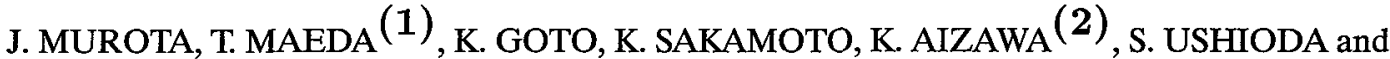 \\ S. ONO
}

Laboratory for Microelectronics, Research Institute of Electrical Communication, Tohoku University, 2-1-1 Katahira, Aoba-ku, Sendai 980, Japan

\begin{abstract}
Low-temperature epitaxial growth of $\mathrm{Si} / \mathrm{Si}_{1-\mathrm{x}} \mathrm{Ge}_{\mathrm{X}} / \mathrm{Si}$ heterostructures at high Ge fractions on Si(100) was investigated under the cleanest possible reaction environment of $\mathrm{SiH}_{4}, \mathrm{GeH}_{4}$ and $\mathrm{H}_{2}$ or Ar using an ultraclean hot-wall low-pressure chemical vapour deposition (LPCVD) system. It was found that relatively lower deposition temperatures were suitable for higher Ge fractions in order to prevent island growth of the layers during deposition. Atomically flat surfaces and interfaces for the heterostructure containing $\mathrm{Si}_{0.8} \mathrm{Ge}_{0,2}, \mathrm{Si}_{0.5} \mathrm{Ge}_{0.5}$ and $\mathrm{Si}_{0,3} \mathrm{Ge}_{0.7}$ layers were obtained by deposition at 550,500 and $450^{\circ} \mathrm{C}$, respectively. Cross-sectional transmission electron microscope (TEM) images and Raman spectra show that such samples have excellent epitaxial qualities which are not degraded by wet oxidation

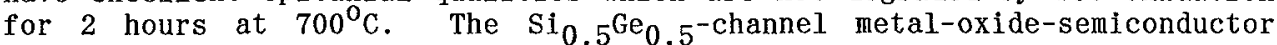
field-effect transistor (MOSFET) having a flat surface has the highest peak field-effect mobility, resulting in the large mobility enhancements of about $70 \%$ at $300 \mathrm{~K}$ and over $150 \%$ at $77 \mathrm{~K}$ compared with those of the MOSFET without the $\mathrm{Si}_{1-\mathrm{x}} \mathrm{Ge}_{\mathrm{X}}$-channel.
\end{abstract}

\section{1.-Introduction.}

The low-temperature epitaxial growth of $\mathrm{Si} / \mathrm{Si}_{1-\mathrm{Xe}} / \mathrm{Si}$ heterostructure has attracted interest for utilizing the improved hole mobility in p-channel MosFET's [1-3] as well as in heterojunction bipolar transistors [4]. As a growth method, CVD offers many advantages, such as high throughput, in-situ doping and selective deposition. Recently, improvements in the quality of gases and CVD equipment have enabled lowtemperature epitaxial growth processing [5-8]. For excellent $\mathrm{Si}_{1-\mathrm{x}^{\mathrm{Ge}}} \mathrm{x}^{-\mathrm{channel}}$ pMOSFET's, high Ge fractions in the strained $\mathrm{Si}_{1-\mathrm{x}} \mathrm{Ge}_{\mathrm{x}}$ layer are necessary. However, devices with an expected good performance have been fabricated only for $\mathrm{Si}_{1-\mathrm{X}} \mathrm{Ge}_{\mathrm{X}}$ layers with $x$ around 0.25 or less, deposited by use of CVD [1-2]. At a higher Ge fraction, heterojunction appears to be degraded by island growth as well as by generation of misfit dislocations due to the larger mismatch between the si and $\mathrm{Si}_{1-\mathrm{Ke}} \mathrm{Ge}_{\mathrm{X}}$ layers [9]. Therefore, it is important that the epitaxial growth process

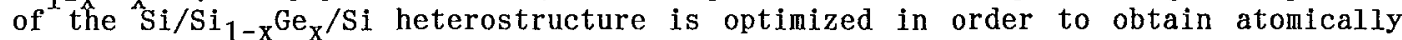
flat surfaces and interfaces at high Ge fractions. In the present work, a lowtemperature epitaxial growth process of the $\mathrm{Si} / \mathrm{Si}_{1-\mathrm{X}} \mathrm{Ge}_{\mathrm{X}} / \mathrm{Si}$ heterostructure has been investigated under the cleanest possible reaction environment of $\mathrm{SiH}_{4}, \mathrm{GeH}_{4}$ and $\mathrm{H}_{2}$ or $\mathrm{Ar}$ using an ultraclean hot-wall low-pressure CVD system[7], enabling to achieve $\mathrm{Si} / \mathrm{Si}_{I-x} \mathrm{Ge}_{\mathrm{X}} / \mathrm{Si}$ heterostructures with atomically flat surfaces and interfaces for

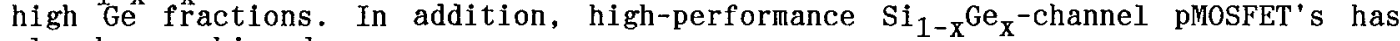
also been achieved.

(1) On leave from Kokusai Electric Co., Ltd., Toyama Works, 2-1 Yasuuchi, Yatsuo-machi, Neigun, Toyama 939-23, Japan

(2)

On leave from Sumitomo Metal Mining Co., Ltd., Central Research Lab., Ichikawa 272, Japan 


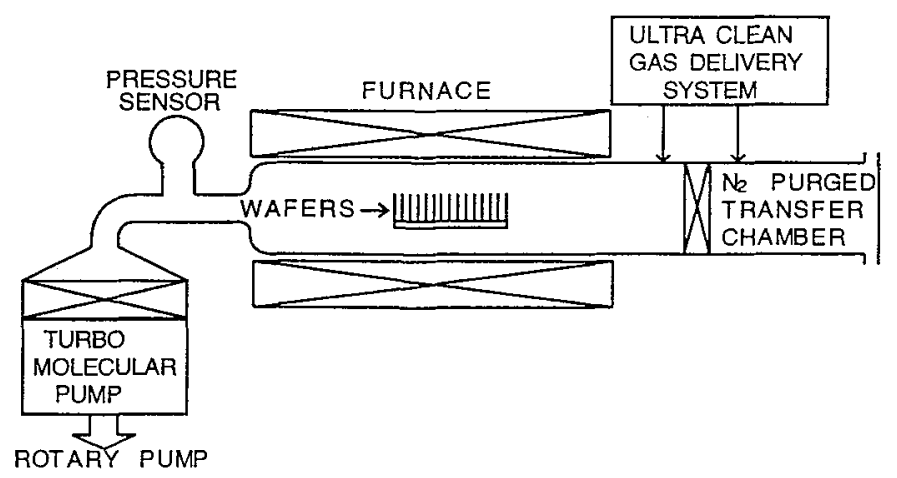

Fig.1.-Schematic diagram of an ultraclean hot-wall LPCVD system.

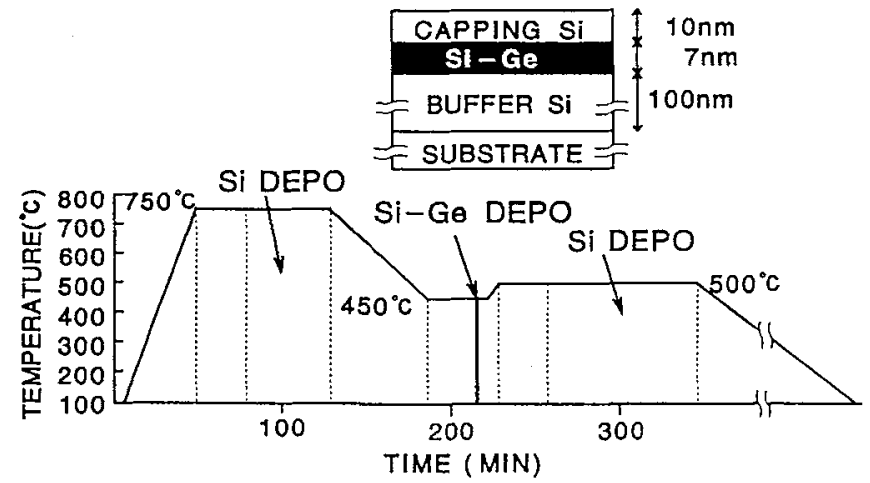

Fig.2.-Typical process sequence for $\mathrm{Si} / \mathrm{Si}_{1-\mathrm{x}} \mathrm{Ge}_{\mathrm{X}} / \mathrm{Si}$ heterostructure growth by ultraclean hot-wall LPCVD system.

\section{2. -Contamination-minimized LPCVD processing.}

The ultraclean hot-wall LPCVD system used in our experiments is schematically shown in Figure 1. [7]. The LPCVD system was made ultrahigh vacuum compatible with gate valves and a turbo molecular pump system. The turbo molecular pump system was improved to vacuum-evacuate from atmospheric pressure. To minimize air-contamination in the reactor during the wafer load and unload, a $\mathrm{N}_{2}$ purged transfer chamber was combined with the reactor inlet. The typical process sequence for $\mathrm{Si} / \mathrm{Si}_{1-x} \mathrm{Ge}_{\mathrm{X}}$ /Si heterostructure growth is shown in Figure 2. The substrates used were $n$-type $\mathrm{Si}$ wafers of 1-3 ohm-cm with mirror polished (100) surfaces. The wafers were cleaned in several cycles in a $4: 1$ solution of $\mathrm{H}_{2} \mathrm{SO}_{4}$ and $\mathrm{H}_{2} \mathrm{O}_{2}$, high-purity DI water, and $1 \% \mathrm{HF}$ with a final rinse in DI water, and the wafers, placed on a quartz boat, were transported into the reactor under ultraclean $\mathrm{N}_{2}$ atmosphere through the transfer chamber. After closing the gate valve, the $\mathrm{N}_{2}$ flow stopped and the reactor tube was purged with high-purity $\mathrm{H}_{2}$. In order to prevent any contamination from the exhaust line, the wafers were transported into the reactor at a reactor temperature of about $100^{\circ} \mathrm{C}$, and then heated-up to the deposition temperature while purging with $\mathrm{H}_{2}$ gas under a pressure of about $200 \mathrm{~Pa}$ [8]. All three layers of the $\mathrm{Si} / \mathrm{Si}_{1-\mathrm{x}} \mathrm{Ge}_{\mathrm{X}} / \mathrm{Si}$ sandwich were grown by thermal decomposition of $\mathrm{SiH}_{4}$ and $\mathrm{GeH}_{4}$. To reduce oxygen and carbon pile-up at the interface between the deposited layer and the Si substrate, a Si buffer layer was deposited at $750^{\circ} \mathrm{C}$ on the Si substrate because impurities adsorbed on substrate were reduced by both thermal desorption and reduction by $\mathrm{SiH}_{4}$ at $750^{\circ} \mathrm{C}$ as shown in Figure 3 . The strained $\mathrm{Si}_{1-\mathrm{X}} \mathrm{Ge}_{\mathrm{X}}$ layer with a typical thickness of $7 \mathrm{~nm}$ was deposited at rather low temperatures between 
450 and $550^{\circ} \mathrm{C}$. Finally, on the top of this heterostructure, a 10 nm-thick si capping layer was deposited at temperatures between 500 and $550^{\circ} \mathrm{C}$. For the deposition of the $\mathrm{Si}_{1-\mathrm{x}} \mathrm{Ge}_{\mathrm{X}}$ and the $\mathrm{Si}$ capping layers, the total gas pressure was about $25 \mathrm{~Pa}$, and the partial pressures of $\mathrm{SiH}_{4}$ and $\mathrm{GeH}_{4}$ were in the range 1-1.4 and 0.03-0.75 $\mathrm{Pa}$, respectively, with $\mathrm{H}_{2}$ or $\mathrm{Ar}$ as carrier gas. Here, the moisture levels of $\mathrm{N}_{2}$, $\mathrm{H}_{2}$ and $\mathrm{SiH}_{4}$ gases used were $10 \mathrm{ppb}$ or lower and that of $\mathrm{GeH}_{4}$ was $23 \mathrm{ppb}$ or lower at the reactor inlet.

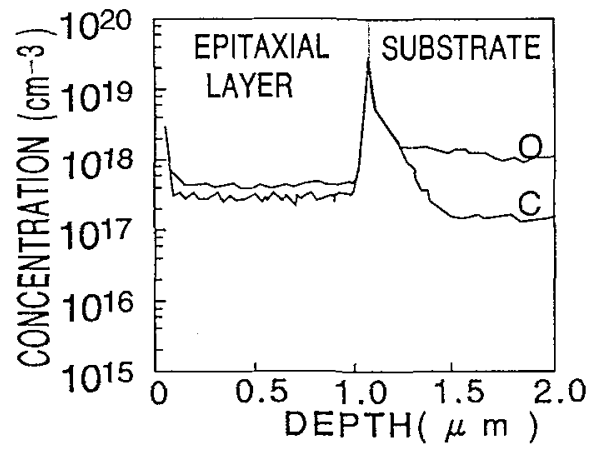

(a)

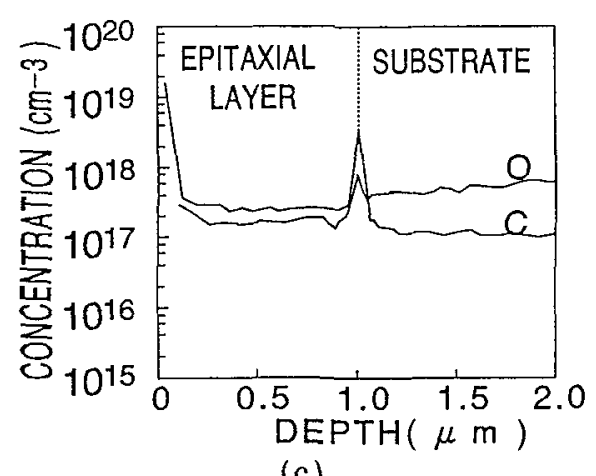

(c)

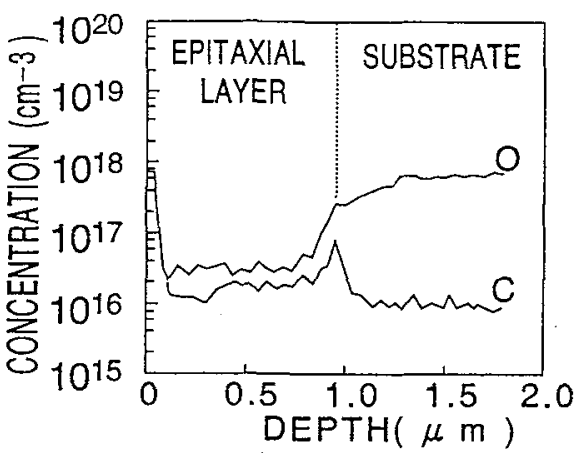

(b)

Fig. 3.-Depth-profiles of oxygen and carbon in the Si epitaxial growth sample, evaluated by secondary ion mass spectrometry. (a) and (b) are the results for the deposition at 600 and $750^{\circ} \mathrm{C}$ after heating-up from about $100^{\circ} \mathrm{C}$. (c) is the result for the deposition at $600^{\circ} \mathrm{C}$ after pre-heating at $750^{\circ} \mathrm{C}$.

\section{3. $-\mathrm{Si} / \mathrm{Si} \mathrm{I}_{1-\mathrm{x}} \mathrm{Ge}_{\mathrm{x}} / \mathrm{Si}$ heterostructure growth at high Ge fractions.}

The influence of the deposition temperatures for the $S i_{1-X} G_{X}$ and $S i$ capping layers, and of the $G e$ fraction of the $S i_{1}-G_{x}$ layer on the surface morphology, observed by scanning tunneling microscopy (STM) is shown in Figures 4 and 5 . It is found that a lower temperature during $\mathrm{Si}_{1-\mathrm{x}} \mathrm{Ge}_{\mathrm{X}}$ and $\mathrm{Si}$ capping layer depositions results in a smoother surface. At a Ge fraction around 0.2 , atomically flat surfaces and interfaces can be obtained by depositing $\mathrm{Si}_{1-\mathrm{x}} \mathrm{Ge}_{\mathrm{x}}$ and $\mathrm{Si}$ capping layers at $550^{\circ} \mathrm{C}$. For higher Ge fractions, however, much lower deposition temperatures are suitable, namely $500^{\circ} \mathrm{C}$ for a $\mathrm{Si}_{0.5} \mathrm{Ge}_{0.5}$ layer and $450^{\circ} \mathrm{C}$ for a $\mathrm{Si}_{0.3} \mathrm{Ge}_{0.7}$ layer, respectively, although no change of heterostructure surfaces with a Ge fraction around 0.7 was detected after the capping layer deposition at temperatures of $550^{\circ} \mathrm{C}$ or less [10]. The values of surface microroughness, obtained for the heterostructures containing the $\mathrm{Si}_{1-\mathrm{x}} \mathrm{Ge}_{\mathrm{x}}$ layers with $\mathrm{x}=0.2,0.5$ and 0.7 deposited at 550,500 and $450^{\circ} \mathrm{C}$, respectively, are comparable to that of the substrate (average surface microroughness $<0.4 \mathrm{~nm}$ ). Our results mentioned above clearly show that lowering the deposition temperature of the $S i_{1}-\mathrm{Ge}_{x}$ lyers is necessary with increasing the Ge fraction to prevent island growth of the heterostructure. By electron diffraction measurements, Kikuchi lines were observed for such heterostructure samples as also shown in Figure 5. 

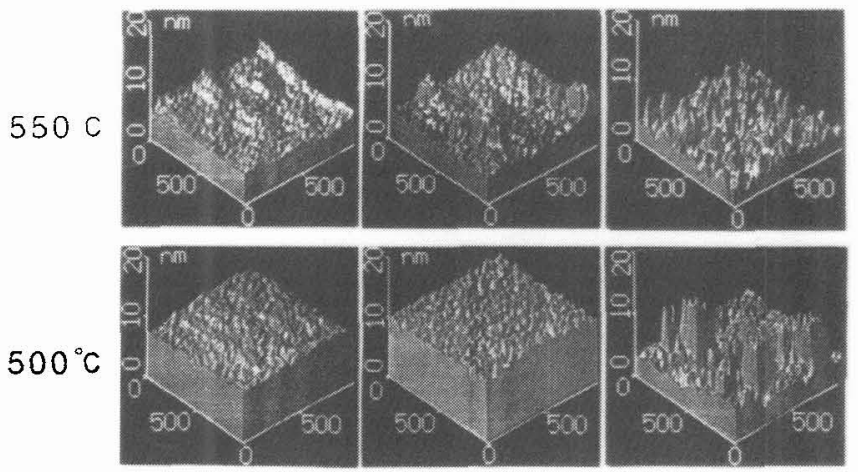

$X=0.2$

$X=0.5$

$X=0.7$

Fig.4.-STM surface morphology of $\mathrm{Si} / \mathrm{Si}_{1-\mathrm{X}} \mathrm{Ge}_{\mathrm{X}} / \mathrm{Si}$ heterostructures, where the $\mathrm{Si}_{1-\mathrm{X}} \mathrm{Ge}_{X}$ layer and the Si capping layer was deposited at 500 and $550^{\circ} \mathrm{C}$. The deposition rate of $\mathrm{Si}_{0.8} \mathrm{Ge}_{0.2}, \mathrm{Si}_{0.5} \mathrm{Ge}_{0.5}$ and $\mathrm{Si}_{0.3^{-}} \mathrm{Ge}_{0.7}$ layers at $500^{\circ} \mathrm{C}$ were $0.46,4.6$ and $22 \mathrm{~nm} / \mathrm{min}$, and those at $550^{\circ} \mathrm{C}$ were $9.7,17$ and $28 \mathrm{~nm} / \mathrm{min}$, respectively. The deposition rates of the capping layer at $500^{\circ} \mathrm{C}$ and $550^{\circ} \mathrm{C}$ were 0.11 and $0.43 \mathrm{~nm} / \mathrm{min}$ respectively.

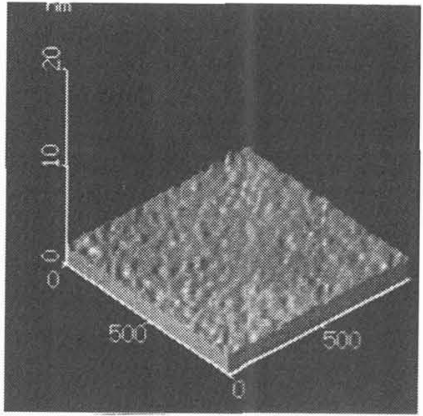

SUBSTRATE

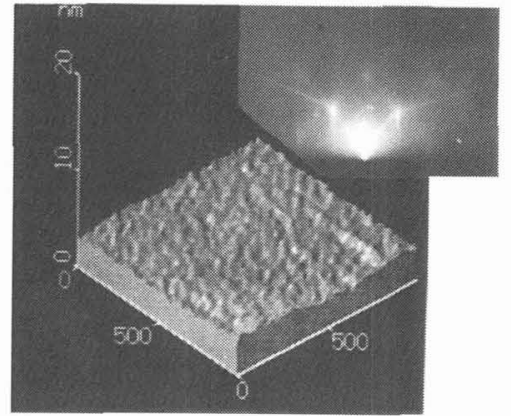

$\mathrm{Si} / \mathrm{Si}_{0.3} \mathrm{Ge}_{0.7} / \mathrm{Si}$

Fig.5.-STM surface morphology and electron diffraction pattern of $\mathrm{Si} / \mathrm{Si}_{0.3} \mathrm{Ge}_{0 .}{ }_{7} / \mathrm{Si}$ heterostructure, where the $\mathrm{Si}_{0.3} \mathrm{Ge}_{0.7}$ and $\mathrm{Si}$ capping layers were deposited at 450 and $500^{\circ} \mathrm{C}$, respectively. The deposition rate of $\mathrm{Si}_{0.3^{6 e}} 0.7$ layer was $3.7 \mathrm{~nm} / \mathrm{min}$.

Cross-sectional TEM images of $\mathrm{Si} / \mathrm{Si}_{1-\mathrm{x}} \mathrm{Ge}_{\mathrm{X}} / \mathrm{Si}$ heterostructures are shown in Figure 6. In the case of $\mathrm{Si} / \mathrm{Si}_{0.8} \mathrm{Ge}_{0.2} / \mathrm{Si}$ and $\mathrm{Si} / \mathrm{Si}_{0.5} \mathrm{Ge}_{0.5} / \mathrm{Si}$ heterostructures deposited at $500^{\circ} \mathrm{C}$ with a flat surface shown in Figure 4 , atomically flat interfaces are observed and the lattice image has no misfit dislocations as shown in Figures 6(a) and $6(\mathrm{~b})$. In the case of $\mathrm{Si} / \mathrm{Si}_{0.3} \mathrm{Ge}_{0.7} / \mathrm{Si}$ heterostructure deposited at $500^{\circ} \mathrm{C}$ with rough surfaces shown in Figure 4 , island growth of the $\mathrm{Si}_{0.3} \mathrm{Ge}_{0.7}$ layer is observed and dislocations are observed in the island growth region as shown in Fugure 6(c). We believe that the critical thickness was exceeded in the island growth region. In the case of $\mathrm{Si} / \mathrm{Si}_{0.3} \mathrm{Ge}_{0.7} / \mathrm{Si}$ heterostructure containing $\mathrm{Si}_{0.3} \mathrm{Ge}_{0,7}$ layer deposited at $450^{\circ} \mathrm{C}$ with a flat surface shown in Figure 5 , atomic order flat interfaces are observed, however, the interface position is indistinguishable as shown in Figure $6(\mathrm{~d})$. By wet oxidation for 2 hours at $700^{\circ} \mathrm{C}$ to perform gate oxide formation, the interface position tends to become more vague than that without oxidation, comparing Figure 6(e) with Figure 6(b), but defect generation is not observed as seen in Figures $6(\mathrm{e})$ and $6(\mathrm{f})$. These results mean the possibility of interdiffusions between $\mathrm{Si}$ and $\mathrm{Ge}$ during $\mathrm{Si} / \mathrm{Si}_{0 .} \mathrm{Ge}_{0.7} / \mathrm{Si}$ heterostructure growth and oxidation [11]. About the interdiffusions, further investigations are necessary. 

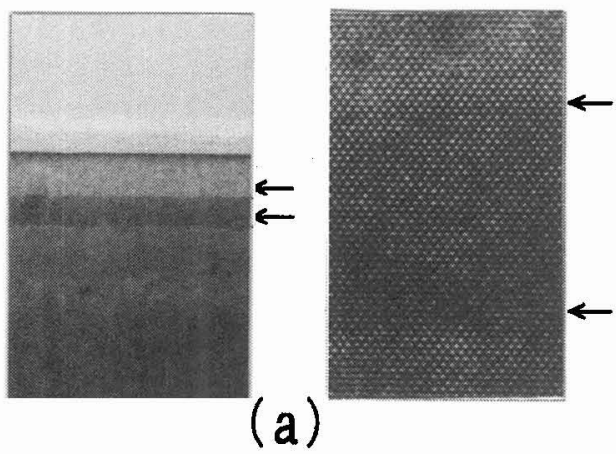

(a)
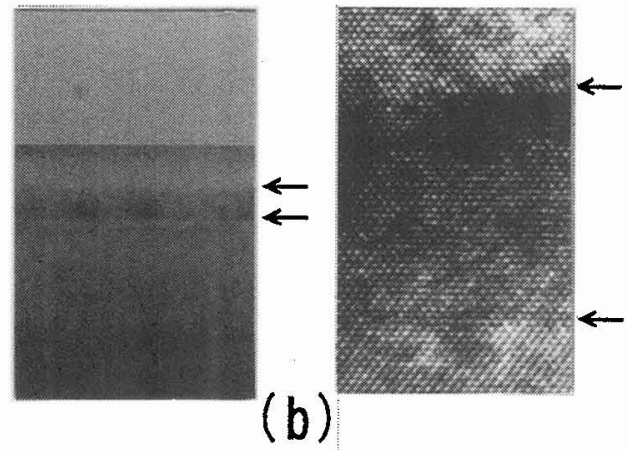

(b)
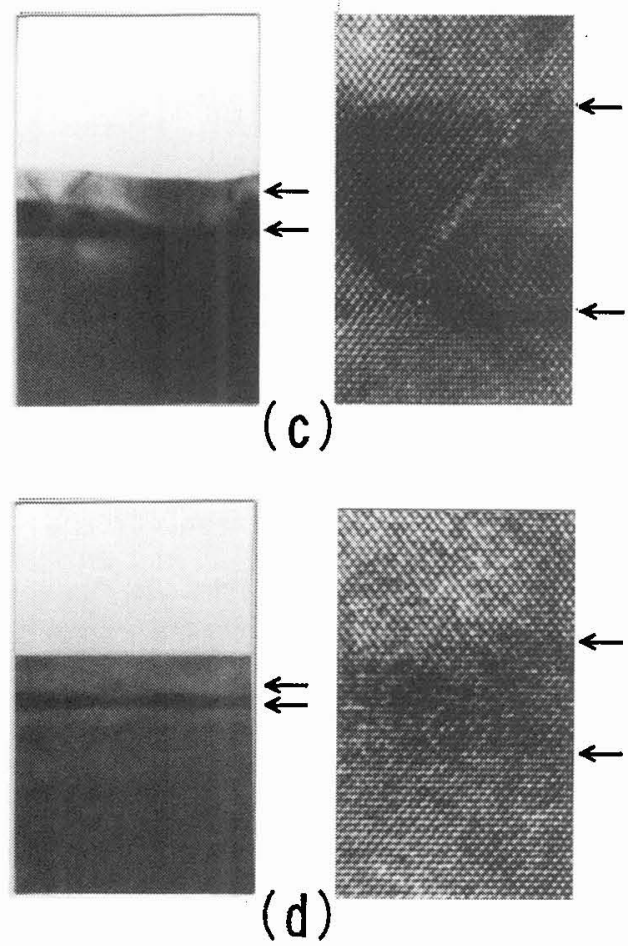

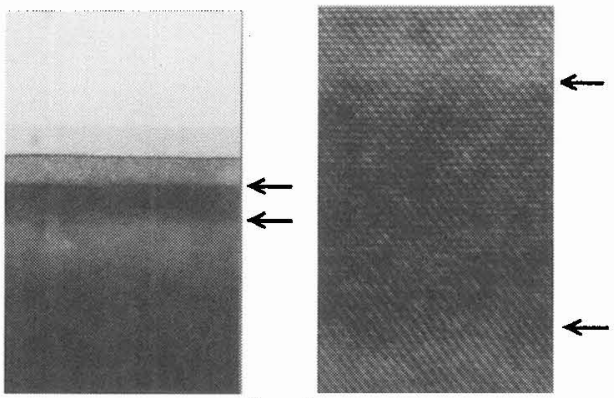

(e)
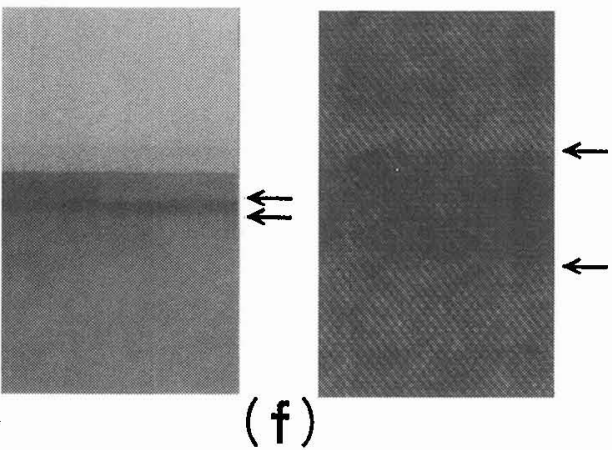

$\longmapsto 40 \mathrm{~nm}$

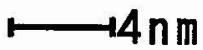

Fig.6. - Cross-sectional TEM images of $\mathrm{Si} / \mathrm{Si}_{1-\mathrm{x}} \mathrm{Ge}_{\mathrm{x}} / \mathrm{Si}$ heterostructures, where $\mathrm{Si}_{1-\mathrm{X}} \mathrm{Ge}_{\mathrm{X}}$ layers of (a), (b) and (c) with the Ge fractions $x$ of $0.2,0.5$ and 0.7 . respectively, were deposited at $500^{\circ} \mathrm{C}$ under the conditions shown in Figure 4 , and the deposition condition of (d) is the same as that in Figure 5. The samples of (e) and (f) were after wet oxidation for 2 hours at $700^{\circ} \mathrm{C}$ of the samples (b) and (d). Arrows indicate the interfaces in the heterostructure. 


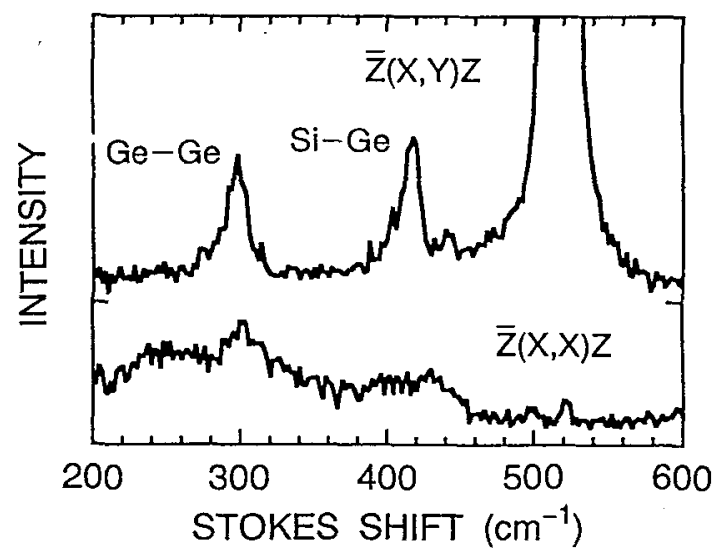

Fig.7.-Raman spectra of $\mathrm{Si} / \mathrm{Si}_{0.5} \mathrm{Ge}_{0.5} / \mathrm{Si}$ heterostructure of Figure $6(\mathrm{~b})$. The configurations of top and bottom spectra are $\bar{Z}(X, Y) Z$ and $\bar{Z}(X, X) Z$, respectively, where $X, Y$ and $Z$ denote $[00 \overline{1}],[010]$ and $[100]$. The resolution of the spectrometer was set at $5 \mathrm{~cm}^{-1}$.

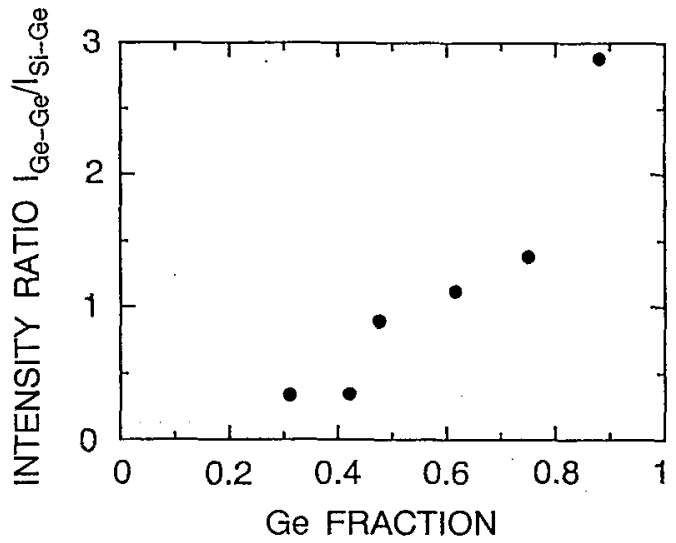

Fig.8.-Relationship between Raman intensity ratio of Ge-Ge peak to $\mathrm{Si-Ge}$ peak and Ge fraction determined by $\mathrm{x}$-ray diffractometry for thicker relaxed $S i_{1-\mathrm{X}} \mathrm{Ge}_{\mathrm{X}}$ layers.

For the above samples, the Ge fraction $x$ in very thin $\mathrm{Si}_{1-\mathrm{x}} \mathrm{Ge}_{\mathrm{X}}$ layers was estimated from the lattice constant of a thicker relaxed $\mathrm{Si}_{1-\mathrm{X}} \mathrm{Ge}_{\mathrm{X}}$ layer, deposited under the same conditions. For a cross check, the Ge fraction $x$ in the very thin $\mathrm{Si}_{1-\mathrm{X}} \mathrm{Ge}_{\mathrm{X}}$ layer of the heterostructure was directly estimated by Raman spectroscopy. The Raman spectra for the sample of Figure $6(\mathrm{~b})$ are shown in Figure 7 . The polarization selection rules of the $\mathrm{Ge}-\mathrm{Ge}$ and the $\mathrm{Si}-\mathrm{Ge}$ vibrations of the $\mathrm{Si}_{0.5} \mathrm{Ge}_{0.5}$ layer are the same as that of the optical phonon of the Si(100) substrate. Figure 8 shows the relationship between Raman intensity ratio of $\mathrm{Ge}-\mathrm{Ge}$ peak to $\mathrm{Si}-\mathrm{Ge}$ peak and $\mathrm{Ge}$ fraction determined by $\mathrm{x}$-ray diffractometry for thicker relaxed $\mathrm{Si}_{1-\mathrm{x}} \mathrm{Ge}_{\mathrm{X}}$ layers. From Figures 7 and 8 , the real Ge fraction is estimated to be about 0.5 , which is nearly equal to that in the thicker relaxed layer. By wet oxidation for 2 hours at $700^{\circ} \mathrm{C}$, the Raman spectra shown in Figure 7 scarcely changed although the decrease of Raman intensity ratio of Ge-Ge peak to Si-Ge peak was observed. Therefore, it is expected that the crystal qualities are not degraded by the above oxidation processing. It should be noted that the degradation of Ge profile was not observed by the above processing within the detection limit of $x$-ray photoelectron spectroscopy [10]. 


\section{3.-Fabrication of a $S i_{1-x} \mathbf{G e}_{x}$-channel MOSFET.}

The MOSFET's with a $100 \mu \mathrm{m}$ gate length and $300 \mu \mathrm{m}$ width were fabricated on the $\mathrm{Si} / \mathrm{Si}_{1-\mathrm{X}} \mathrm{Ge}_{\mathrm{X}} / \mathrm{Si}$ heterostructures deposited under the same conditions as the sample shown in Fîgure 6 using self-aligned Si gate process [12]. A 700nm field oxide was formed at $400^{\circ} \mathrm{C}$ by CVD. A $10 \mathrm{~nm}$ gate oxlde was thermally grown by wet oxidation at $700^{\circ} \mathrm{C}$. Then, in-situ phosphorous doped $\mathrm{n}^{+}$-polysilicon was deposited. The source /drain was formed by $\mathrm{B}^{t}$ implantation $\left(1.2 \times 10^{15} \mathrm{~cm}^{-2}\right.$ at $\left.25 \mathrm{keV}\right)$. All anneal processes were performed at temperatures below $700^{\circ} \mathrm{C}$.

Figure 9 shows threshold voltage and peak field-effect mobility of $\mathrm{Si}_{1-\mathrm{X}^{G}} \mathrm{Ge}_{\mathrm{X}^{-}}$

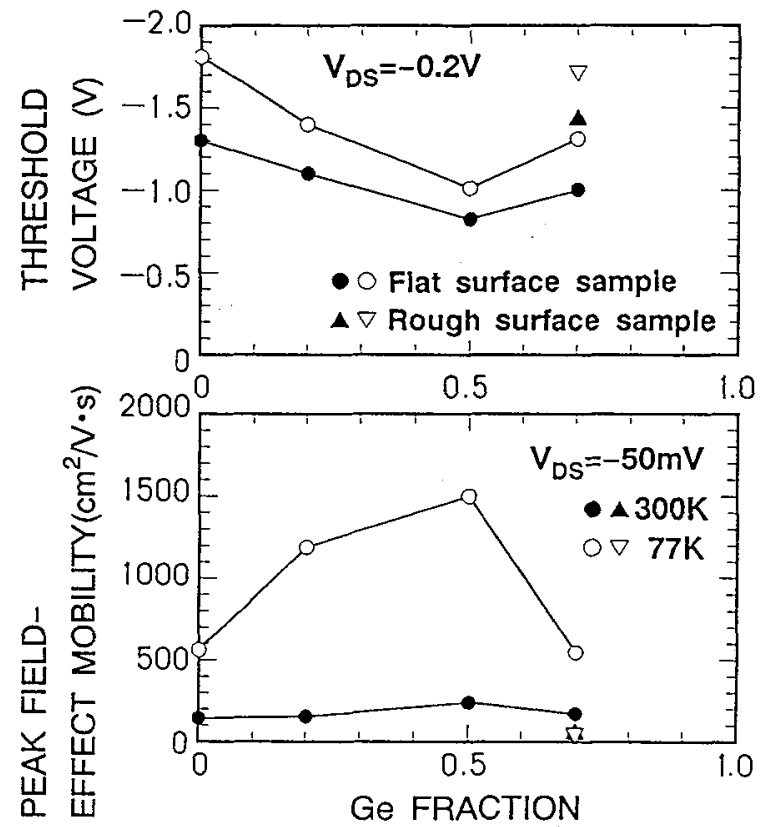

Fig.9-Thershold voltage and peak field-effect mobility of $\mathrm{Si}_{1-\mathrm{X}} \mathrm{Ge}_{\mathrm{X}}$-channel MOSFET

channel MOSFET's having flat surfaces [12]. The $S i_{0}{ }^{-G_{0}} 5^{-c h a n n e l ~ M O S F E T ~ h a v i n g ~ a ~}$ flat surface has the highest peak field effect mobility $9.240 \mathrm{~cm}^{2} / \mathrm{Vs}$ at $300 \mathrm{k}$ and 1500 $\mathrm{cm}^{2} / \mathrm{Vs}$ at $77 \mathrm{~K}$ ), resulting in the large mobility enhancement of about $70 \%$ at $300 \mathrm{~K}$ and over $150 \%$ at $77 \mathrm{~K}$ compared with those of the MOSFET without a $\mathrm{Si}_{1-\mathrm{X}} \mathrm{Ge}_{\mathrm{X}}$-channel [12]. This mobility enhancement is excellent compared with those reported by other investigators $(1,2)$. The subthreshold slopes (about $80 \mathrm{mV} /$ decade at $300 \mathrm{~K}$ and about $30 \mathrm{mV} /$ decade at $77 \mathrm{~K}$ ) of the $\mathrm{Si}_{0.5} \mathrm{Ge}_{0 .}$-channel MOSFET were comparable to those of the MOSFET without a $\mathrm{Si}_{1-\mathrm{X}} \mathrm{Ge}_{\mathrm{X}}-\mathrm{channel}$. This indicates that defect density in the $\mathrm{Si}_{0.5} \mathrm{Ge}_{0.5}$ layer is low. $\mathrm{x}$ on the other hand, the $\mathrm{Si}_{0.3} \mathrm{Ge}_{0.7}$-channel MOSFET has larger threshold voltage and lower peak field-effect mobility, compared with those of the $\mathrm{Si}_{0.5} \mathrm{Ge}_{0.5}$-channel MOSFET. Since the band gap of an unstrained $\mathrm{Si}_{1-\mathrm{Xe}_{X}}$ layer decreases with decreasing Ge fraction and is larger than that of a straîned layer [13], as is well known, it is considered that the Ge fraction decreases, and/or the heterostructure becomes unstrained by generating defects although such defects were not observed in Figure 6(f), during device fabrication. It is also found that the $\mathrm{Si}_{0.3} \mathrm{Ge}_{0.7}$-channel with a rough surface, where the $\mathrm{Si}_{0.3} \mathrm{Ge}_{0.7}$ and capping layers were deposited at $500^{\circ} \mathrm{C}$ (shown in Figure $6(\mathrm{c})$ ), had markediy poor characteristics, that is, very low peak field effect mobility $\left(51 \mathrm{~cm}^{2} / \mathrm{Vs}\right.$ at $300 \mathrm{~K}$ and $55 \mathrm{~cm}^{2} / \mathrm{Vs}$ at $77 \mathrm{~K}$ ) and very large leakage current. This result indicates that the nanometer order surface roughness of the heterostructure degrades the device performance. It was reported that the mobility of MOSFET with a $\mathrm{Si}_{0.6} \mathrm{Ge}_{0.4}$-channel 
was lower than that with a $\mathrm{Si}_{0.7} \mathrm{Ge}_{0.3^{-c h a n n e l, ~ w h e r e ~ b o t h ~ h e t e r o s t r u c t u r e s ~ w e r e ~}}$ grown at around $600^{\circ} \mathrm{C}$ [1]. This reported finding should be caused by island growth of the $\mathrm{Si}_{0} \mathrm{Ge}_{0,4}$ layer. Our results mentioned above clearly show that lowering of the deposition temperatures of the $S i_{1-X} G e_{X}$ layers is more essential for highr Ge fraction to prevent island growth of the heterostructure. For improving MOSFET's with $x$ around 0.7 , further investigations will be necessary.

\section{Acknowledgments.}

The authors wish to express their thanks to Profs. Yasuji Sawada, Kuniyoshi Yokoo and Takashi Matuura, and Drs. Reiner Schutz and Roland Kircher for their advice and encouragement in executing this study. The CVD reactor was provided by Kokusai Electric Co. Ltd. This study was carried out in the superclean Room of the Laboratory for Microelectronics, Research Institute of Electrical Communication, Tohoku University, and was partially supported by Grant-in-Aid for Scientific Research from Ministry of Education, Science, and Culture of Japan.

\section{References.}

[1] GARONE P. M., VENKATARAMAN V. and STURM J. C., IEEE Electron Device Lett. EDL13, (1992) 56 .

[2] VERDONCKT-VANDEBROEK S., CRABBÉ E. F., MEYERSON B. S., HARAME D. L., RESTLE P. J., STORK J. M. C., MEGDANIS A. C., STANIS C. L., BRIGHT A. A., KROESEN G. M. W. and WARREN A.C., IEEE Electron Device Lett. EDL-12, (1991) 447 .

[3] NAYAK D. K., WOO J. C. S., PARK J. S., WANG K.-L. and MACWLLLIAMS K. P., IEEE Electron Device Lett. EDL-12, (1991)154.

[4] SMITH C. and WELBOURN A. D., in Proceedings of the 1987 Bipolar Circuits and Technology Meeting, Sept.21-22, 1987, edited by J.Jopke, (IEEE Electron Device Society, Minneapolis, 1987), p.57.

[5] MEYERSON B. S., Appl.Phys.Lett. 48, (1986) 797.

[6] MEYERSON B. S., URAM K. C. and LEGOUES F. K., Appl.Phys.Lett. 53, (1988) 2555.

[7] MUROTA J., NAKAMURA N., KATO M., MIKOSHIBA N. and OHMI T., Appl.Phys.Lett. 54, (1989) 1007.

[8] MUROTA J., KATO M., KIRCHER R. and ONO S., J.Phys.IV France 1, (1991)C2-795

[9] BEAN J. C., FELDMAN L. C., FIORY A. T., NAKAHARA S. and ROBINSON I. K., J.Vac. Sci.Technol. A2, (1984) 436 .

[10] SCHÜTZ R., MUROTA J., MAEDA T., KIRCHER R., YOKOO K. and ONO S., Appl.Phys. Lett. 61, (1992) 2674 .

[11] SUEMITSU M., CHIBA K. and MIYAMOTO N., Jpn.J.Appl .Phys. 29, (1990) L1591 .

[12] GOTO K., MUROTA J., MAEDA T, SCHUTZ R. AIZAWA K., KIRCHER R. YOKOO K. and ONO S., Jpn.J.Appl.Phys. 32, (1993) 438 .

[13] PEOPLE R., Phys.Rev. B32, (1985) 1405. 